\title{
First, Do No Harm: Evaluating Resources for Teaching Social Entrepreneurship
}

\author{
CHARLENE ZIETSMA \\ York University \\ RICHARD TUCK \\ University of Victoria
}

\begin{abstract}
We reviewed two key repositories of social entrepreneurship pedagogical resources: Ashoka.org and CasePlace.org. Each provides a set of useful resources, comprising videos, syllabi, cases, readings and other resources that make it easy for instructors to design social entrepreneurship courses, modules, or programs. We caution against what we see as overenthusiasm for the topic, however, since social entrepreneurship involves tinkering with social structures, sometimes with disastrous unintended effects. We advise instructors to teach their students to think critically about social entrepreneurship initiatives, since they include the potential for harm as well as good.
\end{abstract}

Seldom has an area of scholarship been as community oriented and as resource rich as social entrepreneurship. Like the social entrepreneurs we study and teach about, academics appear to have absorbed the passion associated with social entrepreneurship and used it to productively create and openly share resources. Furthermore, because social entrepreneurship is often seen as a panacea for social value creation by successful entrepreneurs and business people seeking to "give back," governments seeking private solutions for public problems, and nongovernmental organizations (NGOs) facing difficult funding environments, around the globe substantial time, talent, and money have been invested in facilitating social entrepreneurship.

As a result, there are several key repositories of pedagogical materials and resources for teaching social entrepreneurship. These include Ashoka; CasePlace.org (established by the Aspen Institute); University Network for Social Entrepreneurship (still available on-line but inactive since 2008); Next Billion (established by the World Resources Institute); and the Center for the Advancement of Social Entrepreneurship (CASE) at Duke University. This is not an exhaustive list but serves to show a variety of institutions are involved in the advancement of social entrepreneurship education. We focus on comparing Ashoka with CasePlace.org, chosen for their distinct offerings and renowned status within the social entrepreneurship teaching community.

\section{Ashoka.org}

Founded by social entrepreneurship pioneer Bill Drayton, Ashoka has a mission to "shape a global, entrepreneurial, competitive citizen sector: one that allows social entrepreneurs to thrive and enables the world's citizens to think and act as changemakers" (www.Ashoka.org, accessed March 8, 2011). Ashoka supports individual social entrepreneurs around the world through Ashoka Fellowships. Ashoka's pedagogical resources, meant to inspire as well as educate, are housed on its website in three virtual rooms-the Audio Room, the Print Room, and the Video Room.

The Audio Room contains 15 podcasts featuring interviews with Ashoka Fellows describing their social ventures, and with Bill Drayton. The Print Room houses 12 publications that are mostly specific to Ashoka. The Video Room contains the most

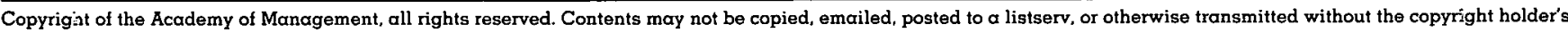


extensive collection of the three, with 110 downloadable clips of varying length and quality. The vast majority of these clips, both news footage and produced spotlights, showcase individuals (Bill Drayton or Ashoka Fellows) as the main agents of change. As a pedagogical resource, these videos provide educators with the next best thing to a guest speaker. They are mostly brief, impactful, and quite suitable for classroom use. Not only can speakers be inspirational, but also, by giving students a visual perspective of real-world problems and the conditions of poverty, they show convincingly the need for solutions. Two of our favorites here are Mobile Technology Inventions in Rural India: The Case for Building Business-Social Bridges and How Ashoka Social Entrepreneurs are Changing Africa, although many of the stories are also quite good.

AshokaU.org, Ashoka's sister site, has no direct link from Asshoka's homepage, making it difficult to find. The site has three additional pedagogical resources for purchase. First, the Social Entrepreneurship Education Resource Handbook includes a "comprehensive listing of case-studies and academic/practitioner books used to teach Social Entrepreneurship in the classroom" (www.AshokaU. org, accessed August 1, 2011). The handbook also lists relevant conferences and student business plan competitions. At \$75, this handbook may be a relatively inexpensive way to stay current with resources available, although a more dated 2008 version is available for free download (see Brock \& Ashoka's Global Resource Academy, 2008, below). Second, the AshokaU Teaching Resource Guide is billed as a tool for deans, provosts, professors, and other academic leaders seeking to build social entrepreneurship programs, establish or adapt syllabi, or include social entrepreneurship concepts in mainstream courses. Ten exemplary course syllabi are presented along with analysis of areas for improvement and areas of opportunity in social entrepreneurship curricula, following a multistakeholder review of 50 social entrepreneurship syllabi. The guide retails for $\$ 199$, though, which makes it a relatively expensive tool for syllabus development, particularly since the information. will age quickly in this fast moving field. Frugal or resource-constrained faculty could satisfice by searching for syllabi on CasePlace.org or more generally on the Internet, and reading a downloadable paper by Brock and Steiner (2009), ${ }^{1}$ which summarizes the results of a review of 107 syllabi of

\footnotetext{
${ }^{1}$ Debbi Brock compiled the 2008 version of the Social Entrepreneurship Teaching Resources Handbook with Ashoka's Global Resource Academy.
}

social entrepreneurship courses, though this review is also now somewhat dated.

The third resource, the Social Entrepreneurship DVD Series, was created in partnership with the Skoll Foundation and features 16 DVDs on six famous social entrepreneurship figures, including Bill Drayton, Muhammad Yunis, Fazle Abed, and others. These videos, which average about $45 \mathrm{~min}$ in length, describe the life experiences of these social entrepreneurs from their early years up to and during their involvement in social enterprise projects. The videos are somewhat slow moving and may not be sufficiently engaging for the average undergraduate classroom, though they are educational for self-study. A free option is to use the Tedx Ashoka YouTube videos featuring Ashoka Fellows (Ashoka-supported social entrepreneurs) available under the community tab on AshokaU. These videos range from just over $3 \mathrm{~min}$ to $20 \mathrm{~min}$, and the speakers can be quite engaging. We particularly like the videos of Bernard Amadei (cofounder of Engineers Without Borders) and Edgar Cahn (founder of TimeBanks USA), but Rocco Falconer (founder of Planting Promise), a 22-year-old winner of an Ashoka-sponsored social entrepreneurship competition gives an inspiring talk that should not be overlooked, as undergraduate students may identify with Rocco because of his age. This clip can be found on the Tedx page on YouTube.

\section{CasePlace.org}

In contrast with Ashoka's promotions of social entrepreneurship to a broader audience, including social entrepreneurs themselves, CasePlace.org. by the Aspen Institute, is specifically designed to be a "library of teaching resources ... primarily to help faculty incorporate environmental, social and ethical topics into their teaching on business and management" (www.CasePlace.org, accessed June 15, 2011). Cases listed on CasePlace.org are made available through direct links by way of the usual case distributors, such as Harvard Business Publishing, Ivey Publishing, and the European Case Clearing House. While abstracts of materials are available to all users on the website, free inspection copies of cases are only available to registered faculty. Each pedagogical resource is reviewed by a long-time consultant of the Aspen Institute to ensure the item is relevant to CasePlace.org. Registered faculty are also able to rate the resources, although this appears to be a tool which is rarely used. Students and other nonfaculty users, on the other hand, are not able to rate materials and have to pay standard case 
prices (from over $\$ 3$ to over $€ 6$ ) to purchase the cases directly from case distributors through links from CasePlace.org.

CasePlace.org features a useful internal search engine which allows you to search by author, or by any combination of seven subcategories: keyword, discipline, industry, topic, region, product type, or publication year. A search on the keywords "social entrepreneurship" yielded 2,690 matches at the time this article was written. Matches can then be refined by any of the seven categories listed above, each with their own subcategories. Product type, for instance, details syllabi, cases, and teaching modules, among others. An advanced search option is also available, which incorporates all categories and subcategories. The results of the search are displayed in condensed form, with clickable links to expand to abstracts and links for downloading materials.

CasePlace.org also features Partner Pages, which allow partner universities to feature their most innovative teaching materials in their own customized channel, along with teaching modules and reading collections. No social entrepreneurship teaching module is featured in the list. The reading collections include $\alpha$ document that outlines the social entrepreneurship readings, cases, syllabi, and other resources produced by Johanna Mair and colleagues and published by Instituto de Estudios Superiores de la Empresa (IESE).

The well-organized and easily accessible resources available from both CasePlace.org and Ashoka/AshokaU make it easy for instructors to find materials and build a syllabus or module on social entrepreneurship. The ready availability of several types of resources is a huge benefit to faculty, and the Aspen Institute and Ashoka are to be congratulated for developing highly useful mechanisms for cataloging and distributing pedagogical resources in social entrepreneurship.

\section{A Critical Eye on Social Entrepreneurship in the Classroom}

The desire for social entrepreneurship to fix largescale problems in our world such as poverty, water quality, universal education, and gender inequalities has led to the enthusiastic endorsement and facilitation of social entrepreneurship by governments, businesses, social investors, foundations, NGOs, and individuals. In many instances, social entrepreneurship courses, and the pedagogical materials that support them, have focused on the experiences of individual founders and the many positive results associated with the start-up of new social enterprises. Most courses feature guest speakers that are involved in the day-to-day doing of social entrepreneurship. Many courses feature service-learning opportunities that involve students in social enterprise work. It all feels very good-overwhelmingly positive and exciting. However, in our optimism, it is easy to get carried away and forget to ask the tough questions. What are the unintended consequences of meddling in social structures? Could we inadvertently do more harm than good? We have seen with physical ecosystems that impacting one aspect of $\alpha$ system can have disastrous impacts on others. This kind of logic is behind the fictional "prime directive," which guided Starfleet personnel in Star Trek: There was to be "no interference with the internal development of alien civilizations." ${ }^{2}$ At the very minimum, we should be guided by the sentiments of the Hippocratic oath, and do no harm. Yet a more critical and cautious view seems to be mostly missing from the social entrepreneurship pedagogical resources we surveyed, and its absence was especially notable in course syllabi.

When we teach social entrepreneurship in $\alpha$ uniformly positive way, we establish the conditions for the inappropriate spread of unsuitable models of social entrepreneurship. Microlending, for example, has been lauded as a mechanism to enable poor (mostly) women to lift themselves out of extreme poverty, and Muhammad Yunus, founder of the Grameen Bank, has been awarded a Nobel Prize for his work in this area. Recently, and criticizing Grameen Bank directly, Bangladeshi Prime Minister Sheikh Hasina stated, "Micro-lenders make the people of this country their guinea pig. They are sucking blood from the poor in the name of poverty alleviation." She further claimed that microlenders "nurse" poverty to increase their business, and microfinance does not allow people to "escape the poverty trap" (Fund transfer allegations . . 2010: 1). The prime minister's comments follow extensive publicity of microfinance woes in the Andhra Pradesh province in India: Desperate borrowers have reportedly committed suicide to escape their loan commitments, the government has introduced restrictive regulations to protect borrowers from exploitation by microfinance institutions, and repayment rates fell to below $20 \%$ as of April 2011 (Palmer, 2011: 2). Such unintended consequences may result when the sexy veneer of social value creation is applied to profit-seeking ventures, and the institutional context does not have enough restraints in place to prevent the exploitation of the very poor (Ault \& Spicer, 2012).

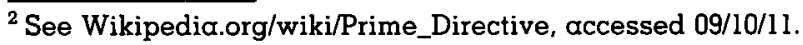


More generally, examples of negative unintended consequences often appear when Band-Aid solutions are applied across multiple contexts without respect to the particular features of the context. For example, Moyo (2009) relates a story of a bed-net supplier who was put out of business by the free distribution of bed-nets, leaving no way of obtaining bed-nets once the free distribution was over. Water systems, community centers, schools, hospitals, and other social institutions throughout poor countries lay in states of disrepair or decay because no one considered that money and skills would be needed to support ongoing operations and maintenance (Burkey, 1993: 38). In part, the development aid mind-set has been supplanted by a social entrepreneurship logic because of these factors.

While "institutional voids" in economic and regulatory institutions (Mair \& Marti, 2009) certainly exist in many development settings, it is also the case that many of these settings feature thick, tightly woven, and mutually reinforcing informal institutions. These can be disrupted, but they will also be defended by socially embedded actors. Since social entrepreneurship is often focused on redistributing wealth to reduce poverty, promoting human rights, and improving the circumstances of disadvantaged groups, its very purpose is to change the fabric of a society. The temporary disruptions of "drive-by aid" or externally driven social entrepreneurship may result only in the reassertion of traditional social structures as soon as the external influence is absent. On the other hand, social structures may unravel disastrously if key threads are pulled.

Programs such as Ashoka's Fellowship program allow for the sensitivity to local context by supporting local social entrepreneurs who understand it. According to Bill Drayton, "We learned that it is a mistake for us to assume that the person we are looking at as a potential Ashoka fellow will do with an idea what we would do. It's got to be what they would do ... About $40 \%$ of our early failures came from that over enthusiasm" (Drayton, 2005). Yet, while Ashoka's mission is focused on establishing a social environment in which change can happen, as indicated by its focus on a citizen sector, the many positive examples available in print and video format on Ashoka's website focus on individuals making a difference, reinforcing the notion of the entrepreneur as the hero. Many of the pedagogical resources available on CasePlace. org, and taught in social entrepreneurship classes around the world, also focus on heroic individuals.

As researchers in the area of institutional change have begun to conclude, it is somewhat naive, and terribly undersocialized, to pin all our understandings of social change on the impacts of individual entrepreneurs (Powell \& Colyvas, 2008). Social entrepreneurship is, by necessity, a social endeavor. Multiple partners must be involved (Haugh, 2005). Social movements must often be mobilized, and political and social systems must have openings for change (McAdam, McCarthy, \& Zald, 1996). Solutions must be theorized and framed (Benford \& Snow, 2000; Greenwood, Suddaby, \& Hinings, 2002).

Currently, few syllabi in social entrepreneurship appear to be addressing these issues. While critiques of social entrepreneurship syllabi (e.g., Brock \& Steiner, 2009; AshokaU Teaching Resource Guide, 2011; Chell, Karatas-Ozkan, \& Nicolopoulou, 2007) have identified lacunce in the scalability of entrepreneurial ventures and in the specific skills of social entrepreneurs at managing multiple bottom lines and motivating volunteers, we see less evidence that social entrepreneurship courses are taking critically evaluative perspectives. We need to teach students to be more thoughtful and consultative about the solutions to be applied based on the context in which they were applied. The skills of an anthropologist and sociologist are as important as those of a business strategist when planning social entrepreneurship efforts that aim to make fundamental changes in social structures.

These concerns bring to the forefront the notion that big problems don't always benefit from big solutions. A common theme among many social entrepreneurship texts is that scale is important: "[Social entrepreneurs'] aim is to identify a pressing and neglected societal problem which, if solved, can lead to many positive spill-overs for society. They devise a sustainable solution to the problem, demonstrate that it can be done and scale it up" (Abhimaniu Mohanty, cited in Santos \& Chowdhry, 2011: 49, emphasis ours). Light (2006) includes seeking sustainable yet "large-scale" change as part of his definition of social entrepreneurship. However, just because poverty is a largescale problem, doesn't mean that it can only be solved by large-scale solutions or by large, wellknown stakeholders. ${ }^{3}$

Banerjee and Duflo note that "[p]overty and development can sometimes feel like overwhelming

\footnotetext{
${ }^{3}$ One of the problems in searching for resources is that they tend to be clogged with examples of corporate social responsibility efforts by large organizations, which fit into some definitions of sustainable entrepreneurship, but not most (Brock \& Steiner, 2009: Appendix A). We believe those examples are not suitable as exemplars of social entrepreneurship.
} 
issues-the scale is daunting, the problems grand. Ideology drives a lot of policies, and even the most well-intentioned ideas can get bogged down by ignorance of ground-level realities and inertia at the level of the implementer" (Banerjee \& Duflo, 2011: chapter 1). Smaller scale efforts that are customized to a local setting are more likely to be successful, particularly when they are focused on capacity development within those settings.

One video that we reviewed for this article nicely draws these ideas together. David Damberger, (2012) the founder of Engineers Without Borders, Calgary, described in a TEDxYYC lecture ${ }^{4}$ how he participated with Engineers Without Borders in installing gravity-fed water systems in Malawi, with funding from the Canadian government. He felt good about reducing the labor of Malawi children by hours each day, and he was treated as a hero when he returned home to Calgary. However, 18 months later, he followed up and found that 81 of the 113 taps his group had installed were not working. The infrastructure had been built, but there was no one to maintain it and no parts. Further digging uncovered that a duplicate system had been funded by the American government a decade earlier, and it, too, was not working. David was encouraged by Engineers Without Borders to talk about the failure so that the organization could collectively learn how to improve. One response was for the organization to shift from drive-by "hardware" installations to spending their efforts developing "software": the planning capabilities of locals for data-driven decision making. Their marketing campaign took the usual "Sponsor an African Child" style of poster and replaced the word "Child," so the slogan read "Sponsor an African Spreadsheet." This powerful 13-min YouTube video sends a strong message to students that intentions are not enough, and solutions that feature local involvement and customization hold out much promise.

We have argued that it is necessary to locally customize solutions for social problems. This only partly addresses concerns about the unintended consequences of social entrepreneurship activities. We also need to ensure there is substantial local involvement in defining the problem and the objectives. Otherwise, rich-country "do-gooders" run the risk of attempting to replicate their own norms and values in locations that just don't need them. There are many views of success. Sandra Waddock and Malcolm McIntosh, in their recent

\footnotetext{
${ }^{4}$ Retrieved from http://www.youtube.com/user/TEDxTalks\#p/ search/0/HGiHU-agsGY
}

book on sustainable enterprise economies, encourage us to redefine wealth as well-being, using indicators such as the Happy Planet Index, (which assesses societies based on measures of life expectancy, life satisfaction, and ecologic footprint) and the Calvert-Henderson Quality of Life Indicators, which include 12 indicators such as education, employment, energy, environment, health, human rights and others (Waddock \& McIntosh, 2011: 34). If we teach our social entrepreneurship students to focus too narrowly on alleviating poverty through increasing income, for example, we may find that we reduce life satisfaction and increase ecologic footprint while reducing poverty. We need to be very cognizant of both the inherently dysfunctional aspects of our own goals and norms, along with potential dysfunctions that are involved in translating them into a totally different setting.

\section{CONCLUSIONS}

Social entrepreneurship is a vibrant topic that evokes passion in both social entrepreneurs and professors. Because of this, there is the potential to not only capture the attention of students, but also to inspire them. Ashoka, CasePlace.org, and other websites are very useful resources for social entrepreneurship, as they provide repositories of pedagogical materials that facilitate teaching. It is up to the social entrepreneurship professor, however, to critically evaluate the materials in order to provide a balanced and up-to-date pedagogy, and to teach students to be careful to do no harm.

\section{REFERENCES}

Ault, J. K., \& Spicer, A. 2012. States and markets at the base of the pyramid (bop): Lessons from the rise and fall of commercial microfinance in Andhro Pradesh. Academy of Management Conference, Boston.

Banerjee, A., \& Duflo, E. 2011. www.pooreconomics.com Accessed on September 2, 2011.

Benford, R. D. \& Snow, D. A. 2000. Framing processes and social movements: An overview and assessment. Annual Review of Sociology, 26: 611-639.

Brock, D. D., \& Ashoka's Global Resource Academy. 2008. Social entrepreneurship teaching resources handbook. Available at http://ashokau.org/resources/social-entrepreneurshipeducation-resource-handbook/. Accessed August 21, 2012.

Brock, D. D., \& Steiner, S. 2009. Social entrepreneurship education: Is it achieving the desired aims? Working Paper available at http://ssrn.com/abstract=1344419.

Burkey, S. 1993. People first: A guide to self-reliant participatory rural development. London, UK: Zed Books.

Chell, E., Karatas-Ozkan, M., \& Nicolopoulou, K. 2007. Social entrepreneurship education: Policy, core themes and devel- 
opmental competencies. International Journal of Entrepreneurship Education, 5: 143-162.

Damberger, D. 2012. Retrieved from http://www.youtube.com/ user/TEDxTalks\#p/search/0/HGiHU-agsGY

Drayton, B. 2005. Entrepreneur for society: Bill Drayton and Ashoka, Ashoka Social Entrepreneurship Video Series. Retrieved from www.Ashoka.org

Fund transfer allegation against Prof Yunus needs inquiry: PM. Financial Express [Dhaka]. Retrieved from http:// www.thefinancialexpress-bd.com/more.php?news_id =1 19351\& date $=$ 2010-12-06. Accessed on December 6, 2010 .

Greenwood, R., Suddaby, R., \& Hinings, C. R. 2002. Theorizing change: The role of professional associations in the transformation of institutionalized fields. Academy of Management Journal, 45: 58-90.

Haugh, H. 2005. A research agenda for social entrepreneurship. Social Enterprise Journal, 1: 1-12.

Light, P. C. 2006. Reshaping social entrepreneurship. Stanford Social Innovation Reviews, 4: 46-51.

Mair, J., \& Marti, I. 2009. Entrepreneurship in and around institutional voids: A case study from Bangladesh. Journal of Business Venturing, 24: 419-435.
McAdam, D., McCarthy. J. D., \& Zald, M. N. 1996. Comparative perspectives on social movements: Political opportunities, mobilizing structures, and cultural framings. New York: Cambridge University Press.

Moyo، D. 2009. Why foreign aid is hurting Africa. The Wall Street Journal, March 21: W1.

Palmer, E. 2011. The Andhra Pradesh microfinance crisis and American payday loans: A comparative ethical study. Available at: http://ssrn.com/abstract $=1855013$. Accessed August 28, 2011.

Powell, W. W., \& Colyvas, J. A. 2008. Microfoundations of institutional theory. In R. Greenwood, C. Oliver, K. Sahlin \& R. Suddaby (Eds.), Handbook of organizational institutionalism: 276-298. Thousand Oaks, CA: Sage.

Santos, F., \& Chowdhry. I. 2011. Gram Vikas A/B: Social entrepreneurship in rural India. In J. Hamschmidt \& M. Pirson (Eds.), Case studies in social entrepreneurship and sustainability: The Oikos collection, vol. 2. Sheffield, UK: Greenleaf Publishing.

Waddock, S., \& McIntosh, M. 2011. SEE change: Making the transition to a sustainable enterprise economy. Sheffield, UK: Greenleaf Publishing.

Charlene Zietsma is an associate professor and the Ann Brown Chair in Organization Studies at the Schulich School of Business, York University. Zietsma completed a PhD in organizational behaviour at the University of British Columbia. Her research focuses on institutional work and entrepreneurship in the context of social and environmental change.

Richard Tuck is $\alpha \mathrm{PhD}$ student at the Gill Graduate School of the Gustavson School of Business at the University of Victoria. Tuck completed an MSc in corporate finance from EDHEC Business School. His research focuses on entrepreneurship in the international context as it relates to sustainability. 
Copyright of Academy of Management Learning \& Education is the property of Academy of Management and its content may not be copied or emailed to multiple sites or posted to a listserv without the copyright holder's express written permission. However, users may print, download, or email articles for individual use. 